\title{
THE EFFECT OF DICTYOCAULUS FILARIA AND PROTOSTRONGYLUS RUFESCENS ON SOME CLINICAL FINDINGS, HEMATOLOGICAL PICTURE AND SOME BIOCHEMICAL PARAMETERS IN SHEEP AT QENA GOVERNORATE
}

Mohamed, A. E. A., Mahmoud, R. M., Ismail, M. M., and Mottelib, A. A. Dept. of Animal Medicine, Faculty of Veterinary Medicine, South Valley University.

\begin{abstract}
This study was carried out on lungworms infested sheep of different ages, sexes and localities at Qena governorate. 33 sheep were infested with lungworm of which 28 sheep infested with large lungworms Dictyocaulus filaria and 5 sheep infested with small lungworms Protostrongylus nifescens. Also, 45 animals of different ages and sexes were proven to be healthy by clinical and laboratory means and used as control for the work The infested sheep were assured for infestations through fecal analysis by Vida technique. The clinical examinations of the infested sheep in this study revealed variations in the severity and duration of symptoms. The most prominent signs were coughing which was severe and deep appeared in form of persistent paroxysmal bouts, tachypnea, dyspnea, nasal discharges which were scanty serous or mucopurulent in some cases, auscultation on the chest revealed increase of vesicular murmurs and other infested cases showed moist rales, The respiratory rate and pulse ra.te revealed significant increase in infested sheep rather than the healthy ones while the body temperature was normal in most cases.

Whole blood and serum samples were collected from each sheep for examination of some haematological and biochemical parameters. The haematological investigations for the infested sheep revealed marked decrease In the values of RBCs, Hb and PCV for erythrogrm. However, the leukogram showed significant increase in total leukocytic count due to eosinophilia and neutrophilia accompanied with lymphopenia. The biochemical profile showed significant increase in serum total proteins and globulin levels, significant decrease in $A / G$ ratio and no marked changes in albumin levels between the infested and healthy animal groups.
\end{abstract}




\section{INTRODUCTION}

Verminous pneumonia is an acute, sub acute or chronic infection of the respiratory system of most animals. The disease is a world wide spread among animals in united state of America, Asia, Africa and Middle East including Egypt. The disease in sheep is caused by adult nematode parasites live in the bronchi and causes alveolar and bronchiolar damage (Blood et al., 1983).

The disease causes great economic wasting and losses for the animal wealth. The reported economic failure to win were due to the unthriftiness, retarded growth, reduced production of meat and wooL deaths and the costs for prevention and treatment program.

Some clinical aspects of lung worm infestation in sheep were reported by Sharma and Bhat (1990) and Dhanalakshmi et al., (2002).

The aim of our work was to study the disease problem under a new environmental condition in Egypt.

The work will include the investigation of the causative lungworm parasites in lambs and adult sheep and the associated changes in some blood constituents.

\section{MATERIAL AND METHODS}

\section{Animals:}

animals used in the study were 78 sheep of native breeds with various ages and sexes. They were belonged to different regions at Qena governorate, Egypt. In order to determine the actual number of control healthy and those with parasitic pneumonia, clinical and laboratory examination were conducted to exclude the cases with gastrointestinal parasites infestation. The actual number of the animals included in this 
study were 45 healthy and 33 showing parasitic pneumonia according to the clinical and laboratory investigation. Both the control healthy and diseased groups were further subdivided each into three subgroups according to ages of animals (table, 1).

Table (1): The groups of sheep.

\begin{tabular}{|c||c||c||c||}
\hline Group & Age. Months & Healthy & Infested \\
\hline \hline I & $4-24$ & 15 & 11 \\
\hline 11 & $25-48$ & 15 & 13 \\
\hline III & $49-72$ & 15 & 9 \\
\hline \hline Total & $\mathbf{4 - 7 2}$ & $\mathbf{4 5}$ & $\mathbf{3 3}$ \\
\hline
\end{tabular}

Samples and Methods:

The collected samples from each animal were:

\section{a-Fecal samples:}

Fecal samples were collected from each animal directly from the rectum to choose the control healthy and those with parasitic pneumonia according to Vida technique (Coles, 1986).

\section{b-Blood samples:}

From each animal of the chosen groups two blood samples were collected, the first with anticoagulant EDTA (Ethyline Diamine Tetraacetic Acid) as a whole blood, and the other was obtained on a plain centrifuge tube to obtain clear nonhaemolysed serum.

The whole blood samples were used for the estimation the values of red blood corpuscles count (RBCs), total white blood cells count(WBCs), haemoglobin $(\mathrm{Hb})$ content, packed cells volume (PCV), $\mathrm{MCV}, \mathrm{MCH}, \mathrm{MCHC}$ and differential leukocytic count (Coles, 1986). 
Serum samples were used for the determination the values of total serum proteins (Henry,1964), albumin (Doumas,1971), albumin, globulin and ratio according to Coles ,1986.

The obtained data of results were subjected to statistical analysis according to computer programs (SPSSWIN,1995).

\section{RESULTS}

Results of this investigation include the followings:

\section{1- Clinical examination of animals:}

The general signs that appeared on the diseased infested sheep include unthriftness, depressed appetite, loss of body weight, congested mucous membrane in some cases and bad appearance of wool.

Animals with lung worm infestation showed severe persistent cough III the form of paroxysmal bouts. Diseased animals showed shallow rapid indistinctive abdominal respiration rates .The rates within each infested group were higher than the corresponding healthy control.The mean value of respiratory rate in diseased sheep age between 2-24 months was 49.9/minute (table,3) while in older animals aged 49-72 months was 50.2/minute(table,5). The pulse rates were significantly increased in most of infested diseased animals (table3,4and5).

The body temperature was mainly within the normal values, so insignificant changes between the infested and healthy animals were noticed (tables 3and 4).

\section{2- Lung worms of the animals:}

It was clear from our work that the large lungworm Dictyocaulus filaria was the most common cause of lung infestation in the investigated sheep. 
The small lung worm Protostrongylus rufescens was also recorded III other cases (table,2).

The larvae of both types of lungworms that infested the animals were demonstrated microscopically in their fecal samples (Figl,2 for Dictyocaulus filaria and Fig 3,4 for Protostrongylus rufescens).

\section{3- Effects of lung worms on erythrogram:}

Clear and significant drop was observed in the values of $\mathrm{RBCs}, \mathrm{Hb}$ content and packed cells volume in the infested cases of all animals groups shown in tables 6,7and 8 .

\section{4- Effects of lung worms on leucogram:}

It was clear that the leucogram of the lung worm infested sheep shown in tables 9, 10 and 11 revealed significant increase in WBCs count, eosinophils\% and lymphocytes\%.

Further more, insignificant effect on basophils and monocytes\% while neutrophils and band cells showed significant elevation in infested animals groups 2 and 3.

\section{5- Effects of lung worms on some biochemical parameters:}

The biochemical profile in the infested sheep revealed significant increase in the serum total proteins and globulins, insignificant change in albumins and significant decrease in $\mathrm{A} / \mathrm{G}$ ratio as shown in tables 12,13 and 14 .

Table (2): The common lungworm parasites recorded in sheep.

\begin{tabular}{|c||c||c|}
\hline age & D.filaria & P.rufescens \\
\hline \hline $4-24 \mathrm{~m}$ & 8 & 3 \\
\hline $25-48 \mathrm{~m}$ & 11 & 2 \\
\hline $49-72 \mathrm{~m}$ & 9 & 0 \\
\hline \hline Total & $\mathbf{2 8}$ & $\mathbf{5}$ \\
\hline \hline
\end{tabular}


Mohamed, A. E. A. et al.,

Table (3): The effect of lungworm infestation in sheep aged 4-24m on some clinical parameters.

\begin{tabular}{||c||c|c|c||c|c|c||c||}
\hline \multirow{2}{*}{ Parameters } & \multicolumn{3}{|c||}{ healthy } & \multicolumn{3}{c||}{ infested } & \multirow{2}{*}{ P } \\
\cline { 2 - 5 } & No. & Mean & S.D & No. & Mean & S.D & \\
\hline \hline Respiratory Rate & & 35.4 & 4.9 & & 49.9 & 3.7 & $* *$ \\
\hline Pulse Rate & \multirow{2}{*}{15} & 96.2 & 8.7 & 11 & 102.6 & 6.2 & $*$ \\
\cline { 3 - 4 } & & 39.6 & 0.4 & & 39.74 & 0.6 & N.S \\
\hline Temperature & & &
\end{tabular}

Table (4): The effect of lungworm infestation in sheep aged $25-48 \mathrm{~m}$ on some clinical parameters.

\begin{tabular}{||c||c|c|c||c|c|c||c||}
\hline \multirow{2}{*}{ Parameters } & \multicolumn{3}{|c||}{ healthy } & \multicolumn{3}{c||}{ infested } & \multirow{2}{*}{ P } \\
\cline { 2 - 8 } & No. & Mean & S.D & No. & Mean & S.D & \\
\hline \hline Respiratory Rate & & 29.7 & 2.6 & & 45.38 & 10.5 & $* *$ \\
\hline Pulse Rate & \multirow{2}{*}{15} & 82 & 7.2 & 13 & 91.2 & 5 & $* *$ \\
\cline { 3 - 7 } & & 39.4 & 0.4 & & 39.53 & 0.5 & N.S \\
\hline Temperature & & & &
\end{tabular}

Table (5): The effect of lungworm infestation in sheep aged 49-72m on some clinical parameters.

\begin{tabular}{||c||c|c|c||c|c|c||c||}
\hline \multirow{2}{*}{ Parameters } & \multicolumn{3}{|c||}{ healthy } & \multicolumn{3}{c||}{ infested } & \multirow{2}{*}{ P } \\
\cline { 2 - 8 } & No. & Mean & S.D & No. & Mean & S.D & \\
\hline \hline Respiratory Rate & \multirow{2}{*}{15} & 27.6 & 2.7 & & 50.2 & 6.5 & $* *$ \\
\hline Pulse Rate & 82.13 & 6.7 & 9 & 92.4 & 7.6 & $* *$ \\
\hline Temperature & & 39.26 & 0.4 & & 39.6 & 0.3 & $*$ \\
\hline
\end{tabular}

Table (6): The effect of lungworm infestation on erythrogram in sheep aged 4-24 months old.

\begin{tabular}{|c|c|c|c|c|c|}
\hline \multirow{3}{*}{ Parameters } & \multirow{2}{*}{\multicolumn{2}{|c|}{$\begin{array}{l}\text { Healthy } \\
\text { No. }=15\end{array}$}} & \multirow{2}{*}{\multicolumn{2}{|c|}{$\begin{array}{l}\text { infested } \\
\text { No.= } 11\end{array}$}} & \multirow{3}{*}{$\mathbf{P}$} \\
\hline & & & & & \\
\hline & Mean & S.D & Mean & S.D & \\
\hline$\overline{~ R B C s, T / L}$ & 11.3 & 1.4 & 9.5 & 1.3 & *** \\
\hline $\mathrm{Hb}, \mathrm{g} / \mathrm{dl}$ & 9.77 & 0.8 & 8.4 & 1 & $* *$ \\
\hline PCV, \% & 29.4 & 2.6 & 23.9 & 1.8 & $* *$ \\
\hline $\mathrm{MCV}, \mathrm{fl}$ & 26.31 & 3.2 & 25.6 & 3.5 & $\mathrm{NS}$ \\
\hline $\mathrm{MCH}, \mathrm{pg}$ & 8.75 & 1.1 & 9 & 1.7 & $\mathrm{NS}$ \\
\hline MCHC, g/dl & 33.52 & 4.4 & 35 & 3.7 & NS \\
\hline
\end{tabular}

Kafrelsheikh Vet. Med. J. Vol. 6 No. 1 (2008) 
The Effect Of Dictyocaulus Filaria And Protostrongylus ...

Table (7): The effect of lungworm infestation on erythrogram in sheep aged 25-48 months old.

\begin{tabular}{|c|c|c|c|c|c|}
\hline \multirow{3}{*}{ Parameters } & \multirow{2}{*}{\multicolumn{2}{|c|}{$\begin{array}{l}\text { Healthy } \\
\text { No. }=15\end{array}$}} & \multirow{2}{*}{\multicolumn{2}{|c|}{$\begin{array}{l}\text { infested } \\
\text { No. }=13\end{array}$}} & \multirow{3}{*}{$\mathbf{P}$} \\
\hline & & & & & \\
\hline & Mean & S.D & Mean & S.D & \\
\hline RBCs, $T / L$ & 9.4 & 0.9 & 8.4 & 1.1 & $*$ \\
\hline $\mathrm{Hb}, \mathrm{g} / \mathrm{dl}$ & 9.8 & 0.9 & 7.5 & 1.3 & $* *$ \\
\hline PCV, \% & 30.3 & 2.1 & 24.4 & 1.4 & $* *$ \\
\hline $\mathrm{MCV}, \mathrm{fl}$ & 32.3 & 3.5 & 29.7 & 5 & NS \\
\hline $\mathrm{MCH}, \mathrm{pg}$ & 10.4 & 1.5 & 9.2 & 2.2 & NS \\
\hline $\mathrm{MCHC}, \mathrm{g} / \mathrm{dl}$ & 32.4 & 3.9 & 30.8 & 4.9 & NS \\
\hline
\end{tabular}

Table (8): The effect of lungworm infestation on erythrogram in sheep aged 49-72 months old.

\begin{tabular}{|c|c|c|c|c|c|}
\hline \multirow{3}{*}{ Parameters } & \multirow{2}{*}{\multicolumn{2}{|c|}{$\begin{array}{l}\text { Healthy } \\
\text { No. }=15\end{array}$}} & \multirow{2}{*}{\multicolumn{2}{|c|}{$\begin{array}{c}\text { infested } \\
\text { No. }=9\end{array}$}} & \multirow{3}{*}{$\mathbf{P}$} \\
\hline & & & & & \\
\hline & Mean & S.D & Mean & S.D & \\
\hline RBCs, T/L & 9.1 & 0.91 & 7.76 & 1.47 & $*$ \\
\hline $\mathrm{Hb}, \mathrm{g} / \mathrm{dl}$ & 9.77 & 0.55 & 8.78 & 0.88 & $*$ \\
\hline $\mathrm{PCV}, \%$ & 29.4 & 1.4 & 28.11 & 0.93 & $*$ \\
\hline $\mathrm{MCV}, \mathrm{fl}$ & 32.64 & 3.88 & 37.18 & 5.8 & NS \\
\hline $\mathrm{MCH}, \mathrm{pg}$ & 10.86 & 1.36 & 11.63 & 2.23 & NS \\
\hline $\mathrm{MCHC}, \mathrm{g} / \mathrm{dl}$ & 33.31 & 2.4 & 31.28 & 3.58 & NS \\
\hline
\end{tabular}

Table (9): The effect of lungworm infestation on leucogram in sheep aged 4-24 months old.

\begin{tabular}{|c|c|c|c|c|c|}
\hline \multirow{3}{*}{ Parameters } & \multirow{2}{*}{\multicolumn{2}{|c|}{$\begin{array}{l}\text { Healthy } \\
\text { No. }=15\end{array}$}} & \multirow{2}{*}{\multicolumn{2}{|c|}{$\begin{array}{l}\text { infested } \\
\text { No. }=11\end{array}$}} & \multirow{3}{*}{$\mathbf{P}$} \\
\hline & & & & & \\
\hline & Mean & S.D & Mean & S.D & \\
\hline 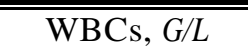 & $\overline{99.5}$ & 2.1 & $\overline{11.5}$ & $\overline{1.2}$ & "** \\
\hline Band cells, \% & 1.5 & 0.9 & 1.3 & 1 & NS \\
\hline Neutrophil. \% & 40.6 & 3 & 43 & 3 & NS \\
\hline Eosinophil, \% & 3.9 & 1.7 & 12.9 & 3 & $* *$ \\
\hline Basophil, \% & 1.5 & 1.1 & 1.3 & 1.2 & NS \\
\hline Lymphocyte, \% & 50.3 & 3.7 & 38.5 & 4.3 & $* *$ \\
\hline Monocyte, \% & 2.3 & 1.1 & 3.1 & 1.4 & $\mathrm{NS}$ \\
\hline
\end{tabular}

Kafrelsheikh Vet. Med. J. Vol. 6 No. 1 (2008) 
Mohamed, A. E. A. et al.,

Table (10): The effect of lungworm infestation on leucogram in sheep aged 25-48 months old.

\begin{tabular}{|c|c|c|c|c|c|}
\hline \multirow{3}{*}{ Parameters } & \multirow{2}{*}{\multicolumn{2}{|c|}{$\begin{array}{l}\text { Healthy } \\
\text { No. }=15\end{array}$}} & \multirow{2}{*}{\multicolumn{2}{|c|}{$\begin{array}{l}\text { infested } \\
\text { No. }=13\end{array}$}} & \multirow{3}{*}{$\mathbf{P}$} \\
\hline & & & & & \\
\hline & Mean & S.D & Mean & S.D & \\
\hline WBCs, $G / L$ & 10.1 & 2.2 & 13 & 2.3 & $*$ \\
\hline Band cells, \% & 1.5 & 0.8 & 1.6 & 1.3 & NS \\
\hline Neutrophil. \% & 40.2 & 2.4 & 42.3 & 3.1 & NS \\
\hline Eosinophil, \% & 2.9 & 1.7 & 10 & 2.2 & $* *$ \\
\hline Basophil, \% & 1.6 & 1.1 & 1.3 & 1 & NS \\
\hline Lymphocyte, \% & 51.1 & 3 & 41.9 & 3.8 & $* *$ \\
\hline Monocyte, \% & 2.7 & 1.1 & 2.8 & 0.7 & NS \\
\hline
\end{tabular}

Table (11): The effect of lungworm on leucogram in sheep aged 49-72 months old.

\begin{tabular}{|c|c|c|c|c|c|}
\hline \multirow{3}{*}{ Parameters } & \multirow{2}{*}{\multicolumn{2}{|c|}{$\begin{array}{l}\text { Healthy } \\
\text { No. }=15\end{array}$}} & \multirow{2}{*}{\multicolumn{2}{|c|}{$\begin{array}{c}\text { infested } \\
\text { No. }=9\end{array}$}} & \multirow{3}{*}{$\mathbf{P}$} \\
\hline & & & & & \\
\hline & Mean & S.D & Mean & S.D & \\
\hline WBCs, $G / L$ & 7.9 & 1.9 & 10.6 & 1.9 & $* *$ \\
\hline Band cells, \% & 1.3 & 1 & 2.9 & 1.2 & $* *$ \\
\hline Neutrophil. \% & 37.3 & 3.6 & 41.2 & 2.7 & $* *$ \\
\hline Eosinophil, \% & 4.3 & 1.8 & 10.3 & 1.4 & $* *$ \\
\hline Basophil, \% & 1.7 & 1 & 1.1 & 0.9 & NS \\
\hline Lymphocyte, \% & 51.9 & 4 & 42.3 & 3.1 & $* *$ \\
\hline Monocyte, \% & 3.5 & 1.2 & 2.1 & 0.8 & NS \\
\hline
\end{tabular}

Table (12): The effect of lungworm infestation on some biochemical parameters In Sheep aged 4-24 months old.

\begin{tabular}{|c|c|c|c|c|c|}
\hline \multirow{3}{*}{ Parameters } & \multirow{2}{*}{\multicolumn{2}{|c|}{$\begin{array}{l}\text { Healthy } \\
\text { No. }=15\end{array}$}} & \multirow{2}{*}{\multicolumn{2}{|c|}{$\begin{array}{l}\text { infested } \\
\text { No. }=11\end{array}$}} & \multirow{3}{*}{$\mathbf{P}$} \\
\hline & & & & & \\
\hline & Mean & S.D & Mean & S.D & \\
\hline Total protein, $g / d l$ & 8 & 0.17 & 8.5 & 0.22 & *** \\
\hline Albumin, $g / d l$ & 3.7 & 0.28 & 3.4 & 0.47 & NS \\
\hline Globulins, $g / d l$ & 4.3 & 0.3 & 5.1 & 0.46 & $* *$ \\
\hline$A / G$ ratio & 0.86 & 0.12 & 0.7 & 0.16 & $* *$ \\
\hline
\end{tabular}

$\overline{\overline{\text { Kafrelsheikh Vet. Med. J. Vol. } 6 \text { No. } 1 \text { (2008) }}}$ 
The Effect Of Dictyocaulus Filaria And Protostrongylus ...

Table (13): The effect of lungworm infestation on some biochemical parameters In Sheep aged 25-48 months old.

\begin{tabular}{|c|c|c|c|c|c|}
\hline \multirow{3}{*}{ Parameters } & \multirow{2}{*}{\multicolumn{2}{|c|}{$\begin{array}{l}\text { Healthy } \\
\text { No. }=15\end{array}$}} & \multirow{2}{*}{\multicolumn{2}{|c|}{$\begin{array}{l}\text { infested } \\
\text { No.= } 13\end{array}$}} & \multirow{3}{*}{$\mathbf{P}$} \\
\hline & & & & & \\
\hline & Mean & S.D & Mean & S.D & \\
\hline Total protein, $g / d l$ & 8.7 & 0.41 & 9.1 & 0.23 & $*$ \\
\hline Albumin, $g / d l$ & 4.3 & 0.38 & 4.1 & 0.2 & NS \\
\hline Globulins, $g / d l$ & 4.4 & 0.5 & 4.97 & 0.32 & $* *$ \\
\hline A $1 G$ ratio & 0.99 & 0.19 & 0.82 & 0.09 & $* *$ \\
\hline
\end{tabular}

Table (14): The effect of lungworm infestation on some biochemical parameters In Sheep aged 49-72 months old.

\begin{tabular}{|c|c|c|c|c|c|}
\hline \multirow{3}{*}{ Parameters } & \multirow{2}{*}{\multicolumn{2}{|c|}{$\begin{array}{l}\text { Healthy } \\
\text { No. }=15\end{array}$}} & \multirow{2}{*}{\multicolumn{2}{|c|}{$\begin{array}{c}\text { infested } \\
\text { No. }=9\end{array}$}} & \multirow{3}{*}{$\mathbf{P}$} \\
\hline & & & & & \\
\hline & Mean & S.D & Mean & S.D & \\
\hline Total protein, $g / d l$ & 8.8 & 0.25 & 9.6 & 0.35 & $* *$ \\
\hline Albumin, $g / d l$ & 4.5 & 0.2 & 4.4 & 0.38 & NS \\
\hline Globulins, $g / d l$ & 4.3 & 0.31 & 5.2 & 0.5 & $* *$ \\
\hline A1G ratio & 1.07 & 0.11 & 0.85 & 0.14 & $* *$ \\
\hline
\end{tabular}

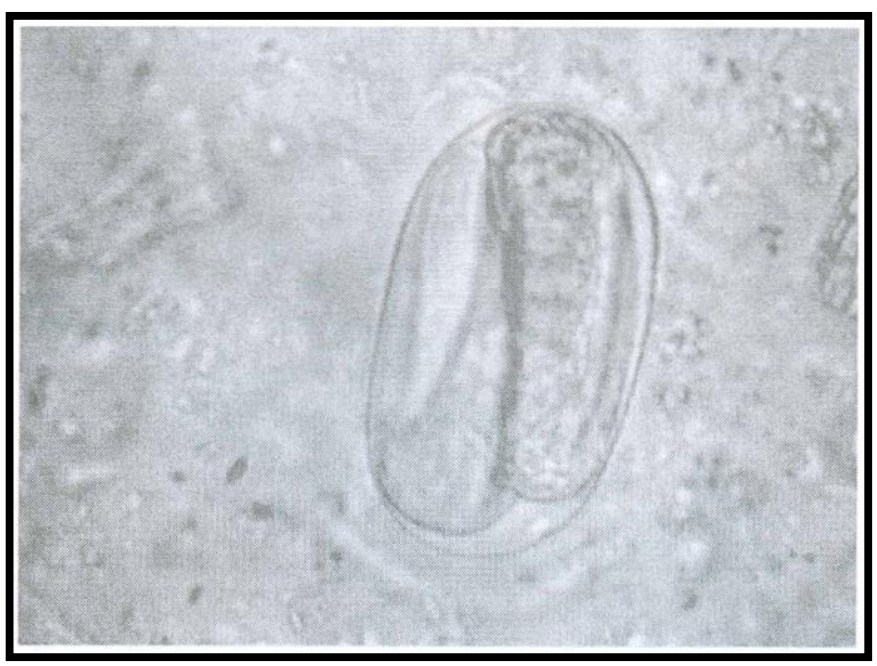

Fig. (1): Egg of D. filaria contain embryo. 


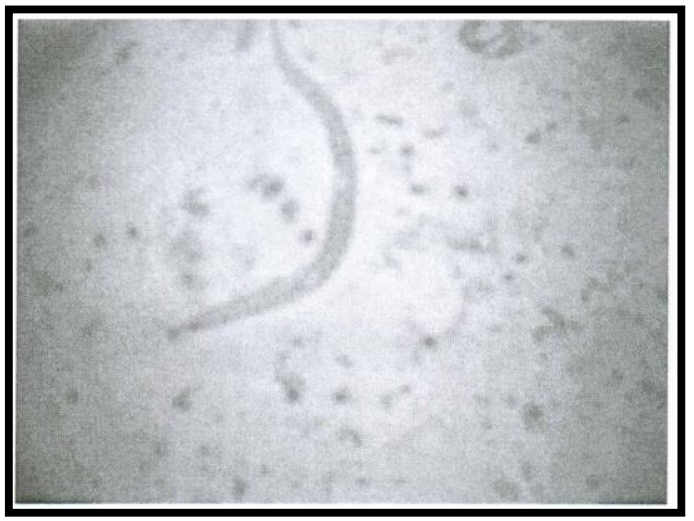

Fig. (2): Larva of D. filaria under $10 \mathrm{obj}$. lens.

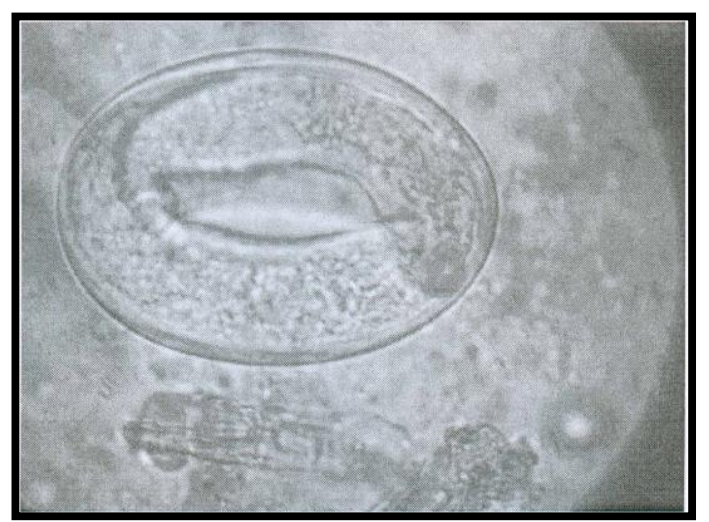

Fig. (3): Egg of P.rufescens contain embryo

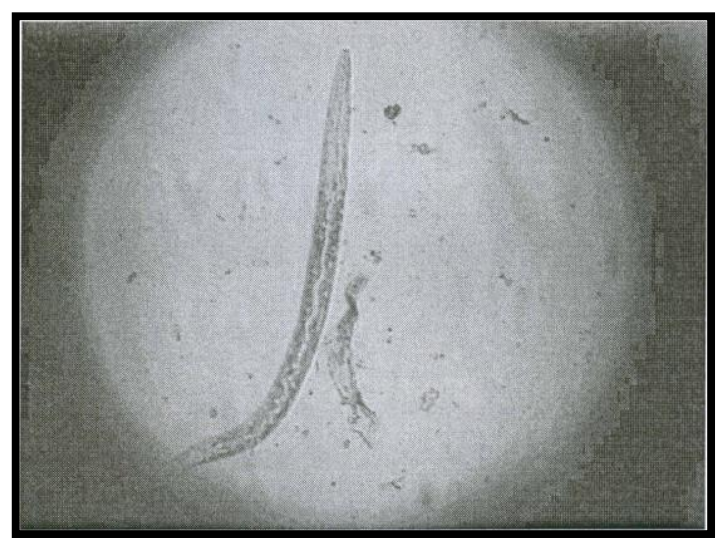

Fig. (4): larva of P.rufescens. 


\section{DISCUSSION}

The paroxysmal bouts of coughing that observed in diseased sheep were due to the irritation of the bronchial mucous membranes by the adult inhabitant worms and the migrating larvae. This coincides with the previous observations reported by Asrani et al., 1999 and Manal, 2002.

The increase in respiratory rate in the infested sheep was due to difficult in respiration as a result of destruction in the pulmonary tissues and obstruction of some bronchioles by impacted adult worms that will interfere with gaseous exchange (Berrag and Cabaret,1996).

The general signs that reported on the diseased infested animals could be attributed to lack of oxygen on the cellular level caused by lung damage and failure of proper gaseous exchange (Smith,1996 and Asrani et al., 1999).

The rise in pulse rate of the infested sheep was in agreement with Radostitis et al, (2002).

The most common causes of lung worm infestation in examined sheep in this study were the large lung worm Dictyocaulus filaria and to a lesser extent the small lung worm Protostrongylus rufescens.

D. filaria has a direct life cycle so the infestation take place by ingestion the $3^{\text {rd }}$ stage larva containing food stuffs of animals, while in $\mathrm{p}$. rufescens has indirect life cycle, so it needs snail as intermediated host for the development of the infective $3^{\text {rd }}$ stage larva, thus needs specific conditions to complete their epidemiological aspects. This explain why large lung worm D. filaria was more predominant in the infested cases of our study than the small lung worm p. rufescens (Matthews, 1999 and Hendrix, 2002). 
The reported decrease of the studied Haematological parameters of our infested animals were similar to that previously reported by Sharma and Bhat, 1997 and Dhanalkshmi et al., 2002 but disagreed with the result obtained by $\boldsymbol{A b d - E I - S a l a m}$ et al., 1992). The reported anemia in sheep infested with lungworm parasites was attributed to osmotic fragility of red blood cells due to the alteration in the constituents of cell membrane (Sharma et al., 1989 and Sharma and Bhat 1997). Also, anemia in the lungworm infested animals was due to blood loss through suckling habits of the adult worms inhabiting the respiratory system (Dhanalkshmi et aI., 2002).

The reported leucocytosis of our infested animals with lungworm parasites was in agreement with Berrag et aI., 1997 and Dhanalakshmi et aI., 2002 but conflicted with Mansfield and Gamble 1995 who found that no significant changes in the total leucocytes between the healthy and lungworm infested animals.

The obtained eosinophilia in all infested cases was similar to that previously reported by Berrag et aI., 1997 and Dhanalakshmi et aI., 2002. The increase of eosinophils in circulation in cases with parasitic infestation was due to the close relationship between the cells and the parasites. The eosinophils were responsible for killing parasites by degranulating on their surface through deposition of major basic proteins into the parasite cuticle and contain specific receptors of complement and immunoglobulins that help in killing of parasites by secreting peroxidases (Jubbs et aI., 1993). 
The obtained neutrophilia of some infested sheep were attributed to the severe pulmonary tissue damage and inflammation that give chance for secondary bacterial infections to complicate the condition (Krishna et aI., 1987).

The reported lymphopnea in the diseased animals may be due to a stress influence (Coles, 1986). The obtained biochemical results for albumen were similar to that previously reported by Jagos et al, (1981) and Sadiek, (1987). But for protein, globulin and AIG ratio as Abd-ElSalam et al .,(1992).

Mulrooney et al, (1989). They reported altration of blood plasma protein values can indicate to diseased conditions. Dhanalakshmi et al., (2002) reorded that the infested sheep revealed significant rise in level of globulin . which occurred due to altration in rate of synthesis of globulin and antiody response against worms and their metabolites and also as a compensatory reactions to restore the reduced serum osmotic pressure because of low albumen concentration.

\section{CONCLUSION}

One method of preventing lungworm infection is to prevent the animals from coming into contact with the infective larvae or the infective intermediate host. This often happens with no effort because many areas and individual farms are free of parasites. Basically a theoretically the avoidance of overcrowding, overgrazing and grazing of excessively moist areas with help and prevent heavy exposures. Strategic anthelmentic treatment to reduce contamination of the premises with eggs and larvae is also helpful. 


\section{REFERENCES}

- Abd-El-Salam, M. N.; Ali, H. S.; Mourad, 1. M.; Dakka, A. A. and Zaitoun, A. M. (1992): Effect of Dictyocaulus filaria and some parasitic infestation in sheep on clinical, hematological and serologicaljindings. Assiut Yet. Med. J. 27, Pp168-173.

- Asrani, R. K.; Batta, M. K.; Katoch, R. C.; Jithendran, K. B.; Sharma, M.; Singh, S. P. and Gupta, Y. K. (1999): Outbreaks of verminous bronchopulmonitis among sheep and goats in Himachal Pradesh. Indian Journal of Animal Sciences 69(4): 207-210.

- Berrag, B. and Cabaret, J. (1996): Impaired pulmonary gas exchange in ewes naturally infected by small lungworms. Int J Parasitol, 26(12): 1397-1400.

- Berrag, B.; Rhalem.; Sahibi.; Dorchies, P. and Cabaret, J. (1997): Bronchoalveolar cellular responces of goats following infections with Muellerius capillaries (Protostrongylidae, nematode). Veterinary Immunology and Immunopathology, 58 (1): 77-88.

- Blood, D. C.; Radostits, O. M.; and Henderson, J. A. (1983): A Text Book of Veterinary Medicine. 6th ED. Bailliere, Tindall, London, UK.

- Coles, E. H. (1986): A text book of veterinary clinical pathology. 4th ED., W.B. Sounder company, Philadelphia, London, Toronto, 331333.

- Dhanalakshmi, H.; Jagannaath, M. S. and Sousa, P. E. $\overline{\bar{K} \text { Kafrelsheikh Vet. Med. J. Vol. } 6 \text { No. } 1 \text { (2008) }}$ 
(2002): Haematological and gamma globulin changes in sheep naturally infected with strongyles. Indian Journal of Animal Sciences, 72 (12): 1094-1095.

- Doumas, B. (1971): Biochemical determination of albumin concentration. Clin. Chem. Acta, 31-87.

- Hendrix, C. M.,(2002): Laboratory procedures for veterinary technicians. Fourth Edition, Mosby, Inc, Pages 35-313.

- Henry, R. J. (1964): Biochemical determination of total protein. Clinical Chemistry, Harper \& Row Publishers. New York, P. 181.

- Jagos, P.; Bouda, J.; Dvorak, V.; and Ondrova, J.,(1981): Comparison of Biochemical Values in the blood plasma of Healthy and Diseased Calves in Large capacity calf house. Veterinarni Medicina, 26(10), Pp: 573-580.

- Jubbs, K. V. F.; Kennedy, P. C. and Palmer, N. (1993): Pathology of domestic animals. $4^{\text {th }}$ Edition, Volume 3, Pages 102-104.

- Krishna, L.; Gupta, V. K. and Katoch, R. C. (1987): Studies on the outbreaks of verminous pneumonia in Gaddi sheep and goats in Himachal Pradesh. Indian Journal of Comparative Microbiology, Immunology and Infectious diseases, 8(4): 170173.

- Manal, H. T. (2002): Some studies on Pneumonia in sheep in Assiut Governorate with special references to antioxidant vitamins. Ph.D. Thesis, Faculty ofVed. Med. Assiut, Egypt. 
- Mansfield, L. S. and Gamble, H. R. (1995): Alveolar mastocytosis and eosinophilia in lambs with naturally acquired nematode infections of Protostrongylus rufescens and Haemonchus contortus. Veterinary Immunology and Immunopathology, Volume 49, Issue 3, Pages 251-262.

- Matthews, J. (1999): Diseases of Goat. Second Edition, Blackwell Science LTD, Page 262- 263.

- Mulrooney, D. M.; Mordine, R . .T.; Bradford, B. S. and Zimmeran, G. L. (1989): Clinical reference value for serum protein Electrophoresis for the Llama (Lamaglama). Am. Vet. Res., 50 (11), Pp: 1889- 1892.

- Radostitis, O. M.; Blood, D. C. and Gay, C. C. (2002): Veterinary medicine. 8 th ED . Baillier Tindall, London.

- Sadiek, A. H., (1987): Clinical and some Biochemical Blood changes accompanying alimentary and respiratory manifestation among fattening Buffaloe calves. M. V. Se., Thesis, Fae. of Vet. Med., Assiut University.

- Sharma, R. L.; Bhat, T. K. and Dhar, D. N. (1989): Effect of Dictyocaulus .filaria infection on osmotic fragility of sheep erythrocytes. Veterinary Parasitology Vol 30, Issue 3, Page 253-258.

- Sharma, R. L. and Bhat, T. K. (1990): Effect of bronchodilator and intravascular oxygen releaser on the course of Dictyocaulus filaria in lambs. Vet Parasitol, 35(1-2): 
147-155.

- Sharma, R. L. and Bhat, T. K. (1997): Effect of sodium acid phosphate and inosine on the course of Dictyocaulus filaria infection in sheep. Indian Journal of Animal Sciences, 68 (1): 17-20.

- Smith, B. P. (1996): Large animal internal medicine. 2 nd Edition, Mosby- Year Book, Inc. USA. Pages 666-667.

تأثثير الديدان الرئوية على الحالة الإكينيكية و صورة الدم و البروتين في الأغنام في محافظة قنا

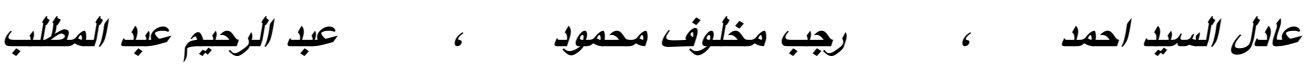

$$
\begin{aligned}
& \text { محد نور الدين إسماعيل } \\
& \text { قسم طب الحيوان كلية الطب البيطري بقتا - جامعة جنوب الوادي }
\end{aligned}
$$

انشتملت هذه الدراسة على عدد 78 حيوان من السلالات المحلية للأغنام المنتشرة في محافظة

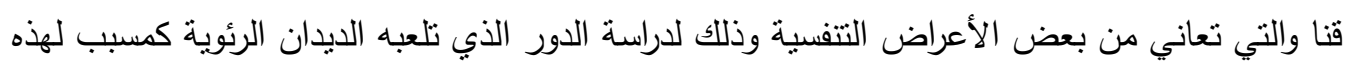
الحالات من خلال الفحص الإكلينيكي لوصف الأعراض الظاهرة على الحيوان ثم الفحص المعلي

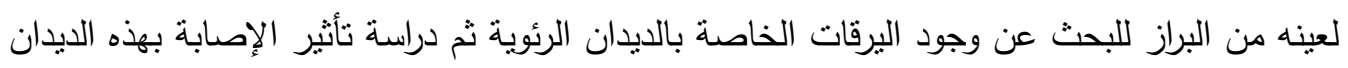
على كل من الحالة العامة للحيوان، صورة الدم بالإضافة إلى بعض المؤشرات البيوكيميائية.

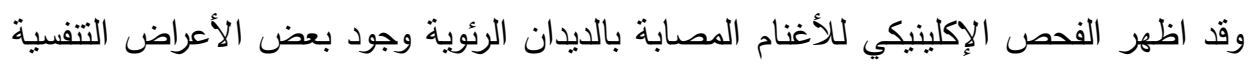

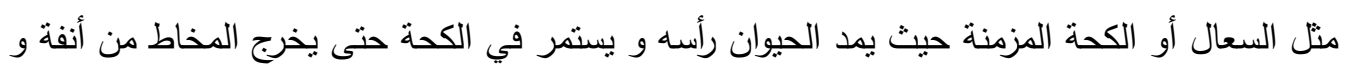

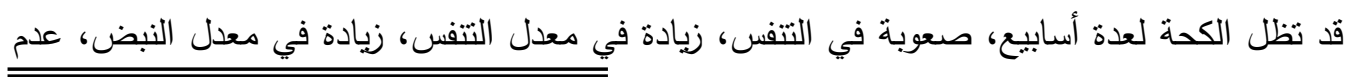
Kafrelsheikh Vet. Med. J. Vol. 6 No. 1 (2008) 


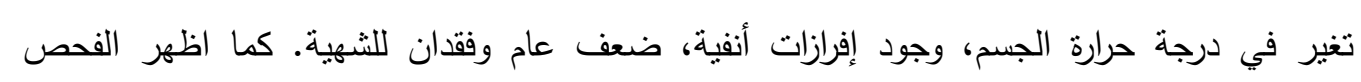
بالسماعة الطبية سرعة دخول وخروج الهواء للرئتين.

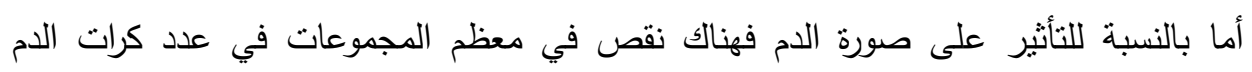
الحمراء، نسبة الهيموجلوبين وحجم الخلايا المضغوطة وزيادة في عدد كرات الدم البيضاء. وقد اظهر العدد النوعي لخلايا الدم البيضاء زيادة في نسبة الخلايا الحمضية وبدرجة اقل الخلايا المتعادلة ونقص في نسبه الخلايا الليمفاوية بين الحيوانان السليمة و المصابة.

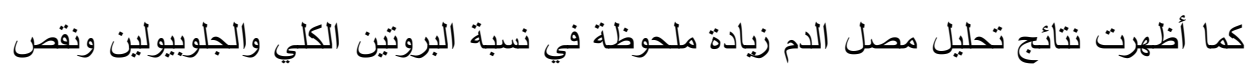
في النسبة بين الألبيومين / الجلوبيولين في حين أن نسبة الألبيومين لم تتأثر كثيرا بسبب إصابة الأغنام بالديدان الرئوية. 